\title{
Analysis Performance of Hospital Based Criteria Malcolm Baldrige in RSUD dr. Iskak Tulungagung Post-Determination of Accreditation Level Plenary
}

Yulikha Rakhmawati ${ }^{1}$

${ }^{1}$ Magister of Health Study Program of STIKes Surya Mitra Husada Kediri ikharakhma@gmail.com
Received : January 25, 2018

Accepted : May 08, 2018

Published : May 11, 2018

\section{ABSTRACT}

Criteria Malcolm Baldrige has a focus on superior performance for the entire organization in a managerial framework that is comprehensive, identify and track all the results of the organization that is the customer, product or service, finance, human resources and organizational effectiveness. The research objective is to analyze the performance of RSUD Dr. Iskak Tulungagung based on criteria Malcolm Baldrige post determination plenary level accreditation. The study design used in the study was cross-sectional. The population is all in addition to the Board of Directors Structural RSUD Dr. Iskak Tulungagung. The sample size was 44 respondents using technique. proportionate stratified random sampling Independent research variables are Leadership, Strategic Planning, Customer Focus or Patient, Measurement, Analysis and Knowledge Management, focus on human resources, focus on the process and results. Data was collected using $a$ questionnaire, then the data were analyzed. The results showed that the majority of respondents have good leadership category as many as 40 respondents $(90.9 \%)$, the Strategic Planning Category well as much as 42 respondents (95.5\%), Customer Focus category patient good or as many as 41 respondents (93.2 $\%$ ), Category Measurement, Analysis and Knowledge Management was good as much as 40 respondents (90.9\%), Category Focus On Human Resource good as much as 34 respondents $(77.3 \%)$, Category Focus On good process as many as 40 respondents ( $90.9 \%$ ), research found criteria organizational criteria based on organizations the Baldrige assessment with 887.4 points as a Word Leader.

Keywords : Accreditation, baldrige assessment, hospital performance.

Copyright (C) 2018 STIKes Surya Mitra Husada

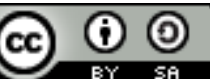

This is an open-acces article distributed under the terms of the Creative Commons Attribution-ShareAlike 4.0 International License. 


\section{INTRODUCTION}

Hospital accreditation is one of the models of the external evaluation method quality of health care. The first hospital accreditation by the American College of Surgeons (ACS) in 1918, from 692 hospitals in the United States that are accredited only 89 who meet the standards. ACS then do accredit hospitals around the world to establish a Joint Commission International (JCI). At the world level formed The International Society for Quality in Health Care (ISQua) which aims to boost the quality and safety of health services (KARS, 2012).

Hospital Indonesia accredited Joint Commission International (JCI) in the first half of 2017 as many as 25 hospitals. While hospitals accredited hospital KARS as many as 1,377 of the 2,175 hospitals. In East Java hospitals that have been accredited as many as 179 of the 392 hospitals. Hospital Dr. Isaac was the only government-owned hospitals Tulungagung type B education accredited plenary (KARS, 2012).

Accreditation is a public recognition through a national body accredits hospitals on hospital achievement in meeting accreditation standards, an assessment expert verified through peer(peer)external independent (KARS, 2012).

Based on observations on service activities RSUD Dr. Iskak Tulungagung still found the service by officers who have the appropriate Standard Operating Procedures (SOPs) which resulted in the complaints of the patient. The report results Minimum Service Standards (SPM) also cannot be achieved $100 \%$ on all service indicators, whereas the Minimum Service Standards (SPM) is the quality of basic services are entitled to be accepted by patients. 2016 achievement of MSS (MSS) amounted to 74.77\%, only 67 indicators were achieved of 90 indicators.

Increasing number of private hospitals that have sprung up in Tulungagung accredited KARS as well as increasing public awareness of quality health services, education level, rapid technological development, the Regional General Hospital Dr. Isaac Tulungagung required to always provide excellent service. As a local government hospital in order to compete with private hospitals, the Regional General Hospital Dr. Isaac Tulungagung optimally utilize market opportunities according to their ability to continue to implement a social function in order to remain the most preferred hospital in Tulungagung society.

According to Djoko Wijono (2009), one of the most appropriate strategies in anticipation of an increasingly open competition is through improving the quality of hospital health care through an integrated quality system(Total QualityManageme nt).Model external evaluation methods other health service quality, among others, the International Organization for Standardization (ISO), Malcolm Baldrige and European Foundation for Quality Management (EFQM) (KARS, 2012).

According Gazpers \& Fontana (2013), Criteria Malcolm Baldrige can assess the effectiveness of the quality system is applied to an organization with the approach of the 7 criteria, namely Leadership(leadership), Strategic Planning(strategic planning),Customer Focus(customer focus),Measurement, Analysis and Knowledge management(measurement, analysis, and knowledge management),Focus on Human Resources(workforce focus),Focus on process(focus operation), Results(result).

Criteria Malcolm Baldrige have a focus on superior performance for the entire organization in a thorough managerial framework, identify and track all the results of the organization that is the customer, product or service, finance, human resources and organizational effectiveness. Quality measurement using Criteria Malcolm Baldrige benefit because it enables the organization conducts Self Assessments(self-assessment).Independent measurement based on the Baldrige Criteria can be performed on various types of good organization of business, nonprofit, education and health (Gazpers \& Fontana, 2013).

According Gazpers and Fontana (2013), the reason for local organizations as well as world-class chose Criteria Malcolm Baldrige as a framework in their management systems, among others, were able to identify strengths and opportunities for improvement, management framework integrated include all the factors that are clear and measurable, focusing the performance requirements to achieve performance excellence is not just application procedures / tools / techniques, easy to adapt to the business environment, can be 
applied to organizations large and small, local organizations as well as world-class, and has proven to be a management practices globally valid for improve organizational performance excellence.

\section{METHOD}

The research design used in the study was cross-sectional. The population is all in addition to the Board of Directors structural RSUD Dr. Iskak Tulungagung. The sample size was 44 respondents using technique. proportionate stratified random sampling Independent research variables are Leadership, Strategic Planning, Customer Focus or Patient, Measurement, Analysis and Knowledge Management, Focus on human resources, focus on the process and results. Data was collected using $a$ questionnaire, then the data were analyzed.

\section{RESULTS}

The results obtained data characteristics of respondents and frequency distribution shown in the table below:

Table 1 Distribution Characteristics based Level Position in hospitals Dr. Iskak Tulungagung

\begin{tabular}{clcc}
\hline No. & \multicolumn{1}{c}{ Position level } & Frequency & Percentage \\
\hline 1 & Head of Division / Section (Echelon 3) & 5 & 11.36 \\
\hline 2 & Heads of Sub-division / section (4 echelon) & 14 & 31.82 \\
\hline 3 & Head Installation & 25 & 56.82 \\
\hline \multicolumn{2}{c}{ Total } & 44 & 100 \\
\hline
\end{tabular}

The characteristics of the 44 respondents in this study is $11,36 \%$ is the third echelon level, as much as $31.82 \%$ is the fourth echelon and as much as $56.82 \%$ is the head of the installation or responsible for the technical service.

Table 2 Distribution Characteristics of Respondents Based Work Period in dr. Isaac Tulungagung

\begin{tabular}{|c|c|c|c|c|c|c|c|c|c|}
\hline \multirow{3}{*}{ No } & \multirow{3}{*}{ Work Period } & \multicolumn{6}{|c|}{ Level Rank } & \multirow{3}{*}{ Total } & \multirow{3}{*}{$\%$} \\
\hline & & \multicolumn{2}{|c|}{ Eselon 3} & \multicolumn{2}{|c|}{ Eselon 4} & \multicolumn{2}{|c|}{ Kepala Instalasi } & & \\
\hline & & $\mathrm{N}$ & $\%$ & $\mathrm{~N}$ & $\%$ & $\mathrm{~N}$ & $\%$ & & \\
\hline 1 & $<10$ Years & 0 & 0 & 3 & 6,82 & 11 & 25,0 & 14 & 31,82 \\
\hline 2 & $>10$ Years & 5 & 11,36 & 11 & 25,0 & 14 & 31,82 & 30 & 68,18 \\
\hline & Total & 5 & 11,36 & 14 & 31,82 & 25 & 58,82 & 44 & 100 \\
\hline
\end{tabular}

the results showed that the majority $(68.18 \%)$ of respondents have a service life of $>$ 10 years and as many as $14(31.82 \%)$ of respondents have a service life $<10$ years of the 3 $(6.82 \%)$ votes echelon level 4 and the head of the installation of $11(25 \%)$ of people. 
Table 3 Distribution Characteristics of Respondents by Education in Hospital Dr. Isaac Tulungagung

\begin{tabular}{|c|c|c|c|c|c|c|c|c|c|}
\hline \multirow{3}{*}{ No } & \multirow{3}{*}{ Education } & \multicolumn{6}{|c|}{ Level Rank } & \multirow{3}{*}{ Total } & \multirow{3}{*}{$\%$} \\
\hline & & \multicolumn{2}{|c|}{ Eselon 3} & \multicolumn{2}{|c|}{ Eselon 4} & \multicolumn{2}{|c|}{ Kepala Instalasi } & & \\
\hline & & $\mathrm{N}$ & $\%$ & $\mathrm{~N}$ & $\%$ & $\mathrm{~N}$ & $\%$ & & \\
\hline 1 & SMA & 0 & 0 & 0 & 0 & 1 & 2,27 & 1 & 2,27 \\
\hline 2 & D3 & 0 & 0 & 0 & 0 & 3 & 6,82 & 3 & 6,82 \\
\hline 3 & SI & 1 & 2,27 & 12 & 27,27 & 12 & 27,27 & 25 & 56,82 \\
\hline 4 & S2 & 3 & 6,82 & 1 & 2,27 & 1 & 2,27 & 5 & 11,36 \\
\hline 5 & Dokter & 0 & 0 & 1 & 2,27 & 1 & 2,27 & 2 & 4,55 \\
\hline \multirow[t]{2}{*}{6} & dr. Spesialis & 1 & 2,27 & 0 & 0 & 7 & 15,91 & 8 & 18,18 \\
\hline & Total & 5 & 11,36 & 14 & 31,82 & 25 & 56,82 & 44 & 100 \\
\hline
\end{tabular}

Based on the survey results revealed that most respondents have S1 as many as 25 respondents $(56.82 \%)$ and at least have a high school education as one of the respondents $(2.27 \%)$ which is the head office level installation.

Table 4 Distribution Characteristics by Age Respondents in Hospital Dr. Isaac Tulungagung

\begin{tabular}{|c|c|c|c|c|c|c|c|c|c|}
\hline \multirow{3}{*}{ No } & \multirow{3}{*}{ Age } & \multicolumn{6}{|c|}{ Level Rank } & \multirow{3}{*}{ Total } & \multirow{3}{*}{$\%$} \\
\hline & & \multicolumn{2}{|c|}{ Eselon 3} & \multicolumn{2}{|c|}{ Selon 4} & \multicolumn{2}{|c|}{ Kepala Instalasi } & & \\
\hline & & $\mathrm{N}$ & $\%$ & $\mathrm{~N}$ & $\%$ & $\mathrm{~N}$ & $\%$ & & \\
\hline 1 & 20-35 Years & 0 & 0 & 2 & 4,55 & 3 & 6,82 & 5 & 11,36 \\
\hline 2 & 36-45 Years & 2 & 2,55 & 5 & 11,36 & 14 & 29,55 & 21 & 47,73 \\
\hline 3 & 46-55 Years & 3 & 6,82 & 5 & 11,36 & 8 & 18,18 & 16 & 36,36 \\
\hline 4 & $>55$ Years & 0 & 0 & 2 & 4,55 & 0 & 0 & 2 & 4,55 \\
\hline & Total & 5 & 11,36 & 14 & 31,82 & 25 & 58,82 & 44 & 100 \\
\hline
\end{tabular}

Based on the survey results revealed that most respondents have a lifespan of 36-45 years as many as 21 respondents $(47.73 \%)$, and at least have aged $>55$ years by two respondents $(4,55 \%)$ at the level echelon 4 .

Table 5 Distribution Characteristics of Respondents by Sex in Hospital Dr. Isaac Tulungagung

\begin{tabular}{|c|c|c|c|c|c|c|c|c|c|}
\hline \multirow{3}{*}{ No } & \multirow{3}{*}{ Sex } & \multicolumn{6}{|c|}{ Level Rank } & \multirow{3}{*}{ Total } & \multirow{3}{*}{$\%$} \\
\hline & & \multicolumn{2}{|c|}{ Eselon 3} & \multicolumn{2}{|c|}{ Eselon 4} & \multicolumn{2}{|c|}{ Kepala Instalasi } & & \\
\hline & & $\mathrm{N}$ & $\%$ & $\mathrm{~N}$ & $\%$ & $\mathrm{~N}$ & $\%$ & & \\
\hline 1 & Male & 3 & 6,82 & 8 & 18,18 & 14 & 31,82 & 25 & 56,82 \\
\hline 2 & Female & 2 & 4,54 & 6 & 13,64 & 11 & 25,0 & 19 & 43,18 \\
\hline & Total & 5 & 11,36 & 14 & 31,82 & 25 & 58,82 & 44 & 100 \\
\hline
\end{tabular}

The survey results revealed that the majority of respondents are male as much as 25 respondents $(56.82 \%)$, and a manifold female sex as much as 19 respondents $(43.18 \%)$. 
Table 6 Performance Based Organization Point Value Malcolm Baldrige.

\begin{tabular}{|c|c|c|c|c|}
\hline \multirow[b]{2}{*}{ No } & \multirow[b]{2}{*}{ Criteria } & \multirow{2}{*}{$\begin{array}{l}\text { Percentage } \\
\text { Value }\end{array}$} & \multicolumn{2}{|c|}{ Malcolm Baldridge } \\
\hline & & & $\begin{array}{l}\text { Maximum } \\
\text { Points }\end{array}$ & $\begin{array}{l}\text { Points } \\
\text { Results }\end{array}$ \\
\hline 1 & Leadership & & & 110,91 \\
\hline $\mathrm{a}$ & Senior leadership & 91,88 & 70 & 64,32 \\
\hline $\mathrm{b}$ & Governance and responsibility & 93,18 & 50 & 46,59 \\
\hline 2 & Strategic planning & & & 81,88 \\
\hline $\mathrm{a}$ & Development strategy & 96,02 & 40 & 38,41 \\
\hline $\mathrm{b}$ & Disemination strategy & 96,59 & 45 & 43,47 \\
\hline 3 & Customer focus/patient & & & 81,6 \\
\hline $\mathrm{a}$ & Market and customer knowledge & 96,31 & 40 & 38,52 \\
\hline $\mathrm{b}$ & Relations and customer satisfaction & 95,74 & 45 & 43,08 \\
\hline 4 & $\begin{array}{l}\text { Measurement, analysis and knowledge } \\
\text { management }\end{array}$ & & & 83,99 \\
\hline $\mathrm{a}$ & $\begin{array}{l}\text { Measurement, analysis and performance } \\
\text { improvement organizations }\end{array}$ & 94,89 & 45 & 42,70 \\
\hline $\mathrm{b}$ & $\begin{array}{l}\text { Information management, information technology } \\
\text { and knowledge }\end{array}$ & 91,76 & 45 & 41,29 \\
\hline 5 & Human resource focus on & & & 73,61 \\
\hline $\mathrm{a}$ & Labor involvement & 77,70 & 45 & 34,97 \\
\hline $\mathrm{b}$ & Labor environment & 96,59 & 40 & 38,64 \\
\hline 6 & Focus on process & & & 80,22 \\
\hline $\mathrm{a}$ & Design of working systems & 96,88 & 35 & 33,91 \\
\hline $\mathrm{b}$ & Management and improvement of work process & 92,61 & 50 & 46,31 \\
\hline 7 & Results the & & & 372,47 \\
\hline $\mathrm{a}$ & Result of products and services & 97,14 & 100 & 97,14 \\
\hline $\mathrm{b}$ & The result focus on customer & 100 & 70 & 70 \\
\hline $\mathrm{c}$ & Results market and financial & 93,33 & 70 & 65,33 \\
\hline $\mathrm{d}$ & Results of human resources & 0 & 70 & 0 \\
\hline $\mathrm{e}$ & The result of the efectivenes of the process & 100 & 70 & 70 \\
\hline $\mathrm{f}$ & Results leadership & 100 & 70 & 70 \\
\hline & Total & & 1000 & 884,68 \\
\hline
\end{tabular}

The results show the number of points of criteria 1- 6 amounted to 512.21 that are in the band score is 481-550, the band number 8, which means the Hospital Dr. Isaac Tulungagung showed remarkable approach(outstanding)focuses on innovation. Approaches deployed fullyand demonstrated superior and sustained use of size. There is a superior integration between approaches to organizational needs. Analysis, learning through innovation, and sharing(sharing)on organizational best practicesare widespread.

\section{DISCUSSION}

Based on the results, the performance criteria that the majority of respondents have a good category (> 76\%) namely Leadership (92.5\%), strategic planning (96.3\%), Customer Focus / patients (96\%), Measurement Analysis and Knowledge Management (93.3), Focus on Human Resources $(87.1 \%)$, Focus On process $(94.7 \%)$. The achievement of the highest performance achieved by strategic planning with the result points approaching the maximum points is 81.9 points. While the lowest points earned gains of the focus on human resources with results of 73.6 points which have maximum points is 85 .

The scoring system Malcolm Baldrige Criteria include the dimensions of the process. The term "process" refers to the method used by organizations to the requirements of item categories 1-6. Four factors in evaluating the process is ADLI, an acronym for: Approach (approach), Deployment (Deployment), Learning (Learning), and Integration (Integration) (Sadikin, 2009). Approach is the method used to enhance or improve the process, the 
accuracy of these methods to the needs or requirement items Criteria, Malcolm Baldrige effectiveness of the method used, the degree or the degree to which such an approach can be repeated and is based on data and information. Deployment is the approach adopted in meeting the requirements of items Malcolm Baldrige Criteria that are relevant and important to the organization or also referred to the approach applied consistently, approach used by all appropriate work units. Learning is an improvement approach through a cycle of evaluation and improvement, support groundbreaking changes to the approach through innovation, and sharing of (sharing) improvements and innovations with other relevant work units and processes within the organization. Integration is an approach that is aligned or integrated with organizational needs identified in the organization's profile or items Criteria. Malcolm Baldrige other Measurement systems, information and complementary enhancement throughout the process and work units. Plans, processes, results, analyzes, lessons learned, and actions to be harmonized throughout the processes and work units to support the scope of the organization's goals (Gazpers \& Fontana, 2013).

Dimensions Results are shown by the results showed that the level of performance(performance level)indicates the place or position in the organization's performance results from the measurement scale meaningfully with good value $>76 \%$. Level of performance allows the evaluation of the comparison of past performance, projections, objectives, and appropriate comparison. The hospital has a tendency(trend)the achievement of a good performance with the performance of the organization or the sustainability of good performance. Human resources performance compared to other hospitals may even be better comparable.

\section{REFERENCES}

Al - Assaf, A.F. (2009). Mutu Pelayanan Kesehatan Prespektif Internasional. Jakarta : EGC.

Ariani, \& Wahyu, D. (2009). Manajemen Kualitas. Yogyakarta : Kanisius.

Azrul, \& Azwar. (2012). Penantar Aministrasi dan Manajemen Kesehatan. Jakarta : Binarupa Aksara.

Bustami. (2011). Penjaminan Mutu Pelayanan Kesehatan dan Akseptabilitasnya. Jakarta : Erlangga.

Donabedian. (2005). Customer Service Satisfaction. Yogyakarta : Andi.

Gazpers, Vincent, Fontana, \& Avanti. (2013). Malcolm Baldrige Criteria for Performance Excellence. Jakarta : PT Gramedia Pustaka Utama.

Gazpers, \& Vincent. (2011). Sistem Manajemen Kinerja TerintegrasiBalanced Score Carddengan Six Sigma untuk Organisasi Jakarta : PT Gramedia Pustaka Utama.

Griffin, \& Jill. (2013). Customer Loyality, Menumbuhkan dan Mempertahankan Kesetiaan Pelanggan. Jakarta : Erlangga.

Guwandi. (2011). Mutu dan Pelayanan Rumah Sakit. Jakarta : Rineka Cipta.

Hadi, \& Anwar. (2010). Sistem Manajemen Mutu. Jakarta : PT Gramedia Pustaka Utama.

Hardjosoedarmo, \& Soewarso. (2014). Bacaan Terpilih Tentang Total Quality Manajemen. Yogyakarta : Universitas Gadjah Mada Press.

Indonesian Quality Award Foundation. (2013). Kriteria Kinerja Ekselen. Jakarta : Yayasan Indonesia Quality Award. 
Juran, I. \& Maxwell, N. Service Management dan Customer Service. Jakarta : Salemba Empat.

Kementrian Kesehatan RI. (2013). Konsep Dasar tentang Pelayanan Rumah Sakit. Jakarta : Kemenkes RI.

Komisi Akreditasi Rumh Sakit. (2012). Buku Saku Akreditasi Rumah Sakit. Jakarta : Publikasi KARS.

Moeheriono. (2012). Pengukuran Kinerja Berbasis Kompetensi Edisi Revisi 2. Jakarta : PT Rajagrafindo Persada.

Muninjaya, G.A. (2011). Manajemen Kesehatan. Jakarta : EGC.

Nasution, M.N. (2012). Manajemen Mutu Terpadu. Bogor : Ghalia Indonesia.

Nusantari, N.K., Taroepratjeka, N., \& Arijanto, S. (2015). Pengukuran Performansi berdasarkan Malcolm Baldrige for Performance Excellence (MBCFPE) pada Kriteria Pengukuran, Analisis dan Manajemen Pegetahuan. Jurnal Manajemen Itenas. Vol 3 (2) : 59 68.

Piot, M., Barton, E., \& McMahon, R. (2010). Manajemen Pelayanan Kesehatan Primer. Jakarta : EGC.

Pohan, I.S. (2013). Jaminan Mutu Layanan Kesehatan : Dasar - Dasar Pengertian dan Penerapan. Jakarta : EGC.

Prawira, A.S., Arijanto, S., \& Nugraha, C. (2013). Sistem Perangkat untuk Internal Assesment Malcolm Baldrige Criteria for Performance Excellence. Jurnal Online Institut Teknologi Nasional Bandung. Vol 1 (2) : $139-149$.

Rangkuti, \& Freddy. (2013). Call Center dan Customer Service. Jakarta : PT Gramedia Pustaka Utama.

Ruky, \& Achmad Sofyan. (2010). Menjadi Manajer Internasional. Jakarta : PT Gramedia Pustaka Utama.

Rulyawan, \& Imam. (2011). Analisis Sistem Pelayanan dan Pendidikan Dokter RSUPN Dr. Ciptomangunkusumo. Tesis Universitas Indonesia.

Sularso, Andi \& Murdjianto. (2014). Pengaruh Penerapan Peran Total Quality.

Supartiningsih, \& Solichah. (2016). Kualitas Pelayanan dan Kepuasan Pasien Rumah Sakit pada asien Rawat Jalan. Jurnal Medicoeticolegal dan Manajemen Rumah Sakit. Vol 6 (1) : 1 -6 .

Undang - Undang Nomor 36 tahun 2009. (2009). Publikasi Undang - Undang Nomor 36 tahun 2009 tentang Kesehatan. Jakarta : Depkes RI.

Undang - Undang Nomor 44 tahun 2009. (2009). Publikasi Undang - Undang Nomor 44 tahun 2009 tentang Rumah Sakit. Jakarta : Depkes RI.

Utami, P \& Setyorini, R. (2014). Analisis Pengaruh Enam Kriteria Lainnya dalam Malcolm Baldrige for Performance Excellence (MBCFPE) to Leadership. Proceeding Management. Vol 1 (3) : $515-533$. 
WHO. (2013). ManagementHospital. www.who.int/gho/en/. Diakses pada 8 Oktober 2017.

Wibowo, \& Arya. (2012). Manajemen Kinerja. Jakarta : PT Rajagrafindo Persada.

Wiyono, Djoko. (2009). Manajemen Mutu Pelayanan Kesehatan : Teori. 